\title{
EDUCAÇÃO BÁSICA NO BRASIL NA DÉCADAA DE 1990: SUBORDINAÇÃO ATIVA E CONSENTIDA À LÓGICA DO MERCADO
}

\author{
GaUdênCIO Frigotto* \\ Maria Ciavatta*
}

\begin{abstract}
E sem dúvida o nosso tempo... prefere a imagem à coisa, a cópia ao original, a representação à realidade, a aparência ao ser... Ele considera que a ilusão é sagrada, e a verdade é profana. E mais: a seus olhos, o sagrado aumenta à medida que a verdade decresce e a ilusão cresce, a tal ponto que, para ele, o cúmulo da ilusão fica sendo o cúmulo do sagrado.
\end{abstract}

$(\text { Feuerbach })^{* * *}$

\begin{abstract}
RESUMO: Este trabalho, apoiado no esforço de análises de pesquisadores e intelectuais que não declinaram do pensamento utópico e, portanto, do esforço de produção de um pensamento crítico a todas as formas de colonialismo, discute a política de educação básica nos dois mandatos do Governo Fernando Henrique Cardoso. A conclusão a que chegamos é a de que a "era FHC" neste particular, também, foi um retrocesso tanto no plano institucional e organizativo quanto, e particularmente, no âmbito pedagógico. Esta conclusão se fundamenta, primeiramente, na análise do tipo de projeto social mais amplo e do projeto educativo a ele articulado, ambos associados de forma ativa, consentida e subordinada aos organismos internacionais.
\end{abstract}

* Doutor pela Pontifícia Universidade Católica de São Paulo (PUC-SP) e professor titular na Faculdade de Educação da Universidade Federal Fluminense (UFF), Rio de Janeiro. E-mail: frigotto@uol.com.br

** Doutora em Ciências Humanas (Educação) pela Pontifícia Universidade Católica do Rio de Janeiro (PUC-RJ) e professora titular em Trabalho e Educação da Universidade Federal Fluminense (UfF), Rio de Janeiro. E-mail: mciavatta@terra.com.br

*** Prefácio da 2a edição de $A$ essência do cristianismo, apud Débord, 1997, p. 13.

Educ. Soc., Campinas, vol. 24, n. 82, p. 93-130, abril 2003

Disponível em <http://www.cedes.unicamp.br> 
No plano mais específico fundamenta-se na relevância da educação básica à luz das questôes mais gerais postas à educação por um mundo em transformação e às políticas educacionais em relação à Lei de Diretrizes e Bases da Educação Nacional e ao Conselho Nacional de Educação, ao Plano Nacional de Educação, ao ensino fundamental e aos Parâmetros Curriculares Nacionais e à reforma do ensino médio e técnico.

Palavras-chave: Educação básica. Governo FHC. Subordinação ativa. Políticas educacionais.

\section{BASIC EDUCATION IN BRAZIL IN THE 1990s: AN ACTIVE AND CONSENTED SUBORDINATION TO THE LOGIC OF THE MARKET}

ABSTRACT: Based on the analyses of researchers and intellectuals who have not abandoned the utopian thinking, that is, on thoughts that criticize any form of colonialism, this paper discusses the basic education policy under the Fernando Henrique Cardoso (FHC) administration (1995-2002). Its conclusions are that the "FHC era" also meant a retrogression both at an institutional and organizational level, and more particularly as for the pedagogical sphere. This conclusion is primarily grounded on an analysis of the broader social project and of the educational project it implied, both associated in an active, consented and subordinate manner with international agencies. More specifically, it is based on the relevance of basic education in the light of more general issues posed to education by a changing world and educational policies concerning the Lei de Diretrizes e Bases da Educação Nacional (Brazilian Education Basic Tenets Law) and the National Educational Council, the National Educational Plan, the 8year compulsory schooling, the National Curriculum Guidelines and the reform of senior high and vocational schools.

Key words: Basic education. FHC government. Active subordination. Educational policies.

\section{Introdução}

$\mathcal{A}$ s últimas décadas do século XX e o início do século XXI vêm marcados por profundas mudanças no campo econômico, sociocultural, ético-político, ideológico e teórico. Em recente coletânea, por nós organizada (Frigotto \& Ciavatta, 2002), analisamos que essas mudanças se explicitam por uma tríplice crise: do sistema capital, éticopolítica e teórica.

No plano mais profundo da materialidade das relações sociais está a crise da forma capital. Depois de uma fase de expansão, denominada 
por Hobsbawm (1995) de idade de ouro, com ganhos reais para uma parcela da classe trabalhadora, particularmente nos países que representam o núcleo orgânico e poderoso do capitalismo, o sistema entra em crise em suas taxas históricas de lucro e exploração. A natureza dessa crise o impulsiona a um novo ciclo de acumulação mediante, sobretudo, a especulação do capital financeiro. Essa acumulação, todavia, não é possível para todos. Instaura-se, então, uma competição feroz entre grandes grupos econômicos, corporações transnacionais que se constituem, na expressão de Noam Chomsky, no poder de fato do mundo. Um poder que concentra a riqueza, a ciência e a tecnologia de ponta de uma forma avassaladora e sem precedentes. Martin \& Schumann sintetizam esta tendência com a idéia metafórica de "sociedade 20 por 80" (1999, p. 7) para designar que apenas uma parcela mínima de $20 \%$ da humanidade efetivamente usufrui da riqueza produzida no mundo. Os demais $80 \%$, que são os que dominantemente a produzem, apropriamse de forma marginal ou são literalmente excluídos.

No plano supra-estrutural e ideológico produz-se um verdadeiro arsenal de noções que constituem, para Bourdieu \& Wacquant (2002), uma espécie de uma "nova língua" com a função de afirmar um tempo de pensamento único, de solução única para a crise e, conseqüentemente, irreversível. Destacam-se as noçōes de globalização, Estado mínimo, reengenharia, reestruturação produtiva, sociedade pós-industrial, sociedade pós-classista, sociedade do conhecimento, qualidade total, empregabilidade etc., cuja função é a de justificar a necessidade de reformas profundas no aparelho do Estado e nas relações capital/trabalho.

Essas reformas vêm demarcadas por um sentido inverso às experiências do socialismo real e das políticas do Estado de bem-estar social do após a Segunda Guerra Mundial, lidas pelos intelectuais orgânicos do sistema capital como responsáveis por um desvio dos mecanismos naturais do mercado e, portanto, pela crise. Trata-se, então, de retomar os mecanismos de mercado aceitando e tendo como base a tese de Hayek (1987) de que as políticas sociais conduzem à escravidão e a liberdade do mercado à prosperidade. O documento produzido pelos representantes dos países do capitalismo central, conhecido como Consenso de Washington, balizou a doutrina do neoliberalismo ou neoconservadorismo que viria a orientar as reformas sociais nos anos de 1990. É neste cenário que emerge a noção de globalização carregada, ideologicamente, por um sentido positivo. ${ }^{1}$

Ao contrário da perspectiva internacionalista do ideário socialista, de uma igualdade substantiva perante o acesso aos bens econômicos, 
culturais e simbólicos, a noção de globalização traz uma inversão daquilo que se concretiza na realidade, total liberdade para o que Chesnais (1996) denomina de "mundialização do Capital". Uma realidade que Mészáros (2002) define como o fim da capacidade civilizatória do capital, para designar o que agora, para manter as taxas históricas de exploração, o capital tem que destruir um a um, os direitos conquistados no contexto das políticas do Estado de bem-estar social.

Os protagonistas destas reformas seriam os organismos internacionais e regionais vinculados aos mecanismos de mercado e representantes encarregados, em última instância, de garantir a rentabilidade do sistema capital, das grandes corporações, das empresas transnacionais e das nações poderosas onde aquelas têm suas bases e matrizes. Nesta compreensão, os organismos internacionais, como o Fundo Monetário Internacional (FMI), Banco Mundial (BIRD), o Banco Interamericano de Desenvolvimento (BID) e o Programa das Naçôes Unidas para o Desenvolvimento (PNUD), passam a ter o papel de tutoriar as reformas dos Estados nacionais, mormente dos países do capitalismo periférico e semiperiférico (Arrighi, 1998). No plano jurídico-econômico, a Organização Mundial do Comércio (OMC) vai tecendo uma legislação cujo poder transcende o domínio das megacorporações e empresas transnacionais. É interessante ter presente o papel da OMC, pois em 2000, numa de suas últimas reuniōes, sinalizou para o capital que um dos espaços mais fecundos para negócios rentáveis era o campo educacional.

Em nível regional, vários organismos são criados como uma espécie de ramificações ou base de apoio para os organismos internacionais. Em termos de América Latina, podemos destacar, no plano econômico, a Comissão Econômica para a América Latina e Caribe (CEPAL) e, no plano educacional, como veremos a seguir, a Oficina Regional para a Educação na América Latina e no Caribe (OREALC). Num plano mais geral situa-se o Acordo de Livre Comércio das Américas (ALCA), cujo escopo se situa dentro da doutrina da Organização Mundial do Comércio.

Um dos efeitos devastadores do pensamento único, sem dúvida, manifesta-se no abandono do pensamento crítico vinculado a projetos societários firmados na perspectiva da autonomia e, ao mesmo tempo, num relacionamento soberano entre povos, culturas e nações. Reafirmam-se, pela via do pragmatismo, das visões positivistas e neopositivisas, e neo-racionalistas e do pós-modernismo, uma visão fragmentária da realidade e uma afirmação patológica da competição e do individualismo. A crise do pensamento comprometido com mudanças pro- 
fundas na atual (des)ordem mundial é, também, a crise do pensamento utópico e da acuidade da teoria social.

Apoiando-nos no esforço de análises de pesquisadores e intelectuais que não declinaram do pensamento utópico e, portanto, do esforço de produção de um pensamento crítico a todas as formas de colonialismo, discutiremos, neste texto, a educação básica no Brasil, nos anos de 1990, à luz do movimento mais amplo internacional que, com o apoio de assessorias, documentos formadores de opinião e de recursos, foi se impondo às políticas públicas de educação com a participação ativa, anuência e colaboração das autoridades locais.

No primeiro momento, refletimos sobre o sentido da educação básica à luz das questôes mais gerais postas à educação por um mundo em transformação. A seguir, analisamos o projeto do Governo Cardoso para a sociedade brasileira e as políticas educacionais com relação à Lei de Diretrizes e Bases da Educação Nacional e ao Conselho Nacional de Educação, ao Plano Nacional de Educação, ao ensino fundamental e aos Parâmetros Curriculares Nacionais e à reforma do ensino médio e técnico. Os temas do financiamento e da avaliação serão abordados em seu sentido político amplo ao discutirmos a prioridade do Governo Cardoso, o ensino fundamental.

\section{Educação básica para um mundo em transformação}

Após o vendaval da queda do muro de Berlim e da idéia do "fim da história" e das ideologias, no caso do Brasil, mas não apenas aqui, explicitou-se um projeto de sociedade que ia na contramão do "pensamento único". Em termos mundiais, especialmente na Europa, houve o retorno das idéias social-democratas ou de um socialismo "cor-de-rosa".

Do ponto de vista da educação, ocorre uma disputa entre o ajuste dos sistemas educacionais às demandas da nova ordem do capital e as demandas por uma efetiva democratização do acesso ao conhecimento em todos os seus níveis. Os anos de 1990 registram a presença dos organismos internacionais que entram em cena em termos organizacionais e pedagógicos, marcados por grandes eventos, assessorias técnicas e farta produção documental.

O primeiro desses eventos é a "Conferência Mundial sobre Educação para Todos" realizada em Jomtien, Tailândia, de 5 a 9 de março de 1990, que inaugurou um grande projeto de educação em nível mundial, para a década que se iniciava, financiada pelas agências UNESCO, 
UNICEF, PNUd e Banco Mundial. A Conferência de Jomtien apresentou uma "visão para o decênio de 1990" e tinha como principal eixo a idéia da "satisfação das necessidades básicas de aprendizagem":

Cada pessoa - criança, jovem ou adulto - deverá estar em condições de aproveitar as oportunidades educacionais oferecidas para satisfazer suas necessidades básicas de aprendizagem. Estas necessidades abarcam tanto as ferramentas essenciais para a aprendizagem (como a leitura e a escrita, a expressão oral, o cálculo, a solução de problemas) como os conteúdos básicos da aprendizagem (conhecimentos teóricos e práticos, valores e atitudes) necessários para que os seres humanos possam sobreviver, desenvolver plenamente suas capacidades, viver e trabalhar com dignidade, participar plenamente do desenvolvimento, melhorar a qualidade de sua vida, tomar decisões fundamentais e continuar aprendendo. A amplitude das necessidades básicas de aprendizagem varia de país a país em sua cultura e muda inevitavelmente com o transcurso do tempo. (WCEA, 1990, p. 157)

Além de representantes de 155 governos que subscreveram a Declaração de Jomtien, ali aprovada, comprometendo-se a assegurar uma "educação básica de qualidade" a crianças, jovens e adultos, dela participaram agências internacionais, organizações não-governamentais, associações profissionais e destacadas personalidades na área da educação em nível mundial. O Brasil, como um signatário entre aqueles com a maior taxa de analfabetismo do mundo, foi instado a desenvolver ações para impulsionar as políticas educacionais ao longo da década, não apenas na escola, mas também na família, na comunidade, nos meios de comunicação, com o monitoramento de um fórum consultivo coordenado pela UNESCO (Shiroma et al., 2002, p. 57-58). ${ }^{2}$

Nesse momento, no Brasil, iniciava-se o governo de Fernando Collor de Melo, que durou pouco mais de um ano, alvo de denúncias que o incriminaram e lhe valeram um processo de impeachment como presidente da República. Mas as bases lançadas pela Conferência inspiraram o Plano Decenal da Educação para Todos, em 1993, já no Governo Itamar Franco. Ao lado do breve sucesso de Collor, naufragara o primeiro projeto popular da esquerda depois da ditadura, a derrota do candidato do Partido dos Trabalhadores, Luiz Inácio "Lula" da Silva. A nova correlação de forças alterará, como veremos adiante, o rumo da nova Lei de Diretrizes e Bases da Educação Nacional (LDB), alimentada pela Constituinte de 1988 e por um amplo movimento da sociedade civil nos anos subseqüentes.

De outra parte, o movimento internacional, que veio alavancar as reformas no Governo Fernando Henrique Cardoso, continuou a 
ganhar expressão por intermédio de outras agências e de outros documentos sobre a educação. Ainda em 1990, a CEPAL publicou Transformación productiva con equidad, que enfatizava a urgência da implementação de mudanças educacionais em termos de conhecimentos e habilidades específicas, demandadas pela reestruturação produtiva. Em 1992, a CEPAL volta a publicar outro documento sobre o tema, Educación y conocimiento: eje de la ttransformación productiva con equidad, vinculando educação, conhecimento e desenvolvimento nos países da América Latina e do Caribe. A urgência era de uma ampla reforma dos sistemas educacionais para a capacitação profissional e o aproveitamento da produção científico-tecnológica ou, em outros termos, dos objetivos "cidadania e competividade", critérios inspiradores de políticas de "eqüidade e eficiência" e diretrizes de reforma educacional de "integração nacional e descentralização" (op. cit., p. 62-63).

A unEsCo e o Banco Mundial completam o quadro principal dos impulsionadores externos das reformas. Entre 1993 e 1996, a Comissão Internacional sobre Educação para o Século XXI, convocada pela UNESCO, composta de especialistas e coordenada pelo francês Jacques Delors, produziu o Relatório Delors, no qual se fez um diagnóstico do "contexto planetário de interdependência e globalização". Evidenciam-se o desemprego e a exclusão social, mesmo em países ricos. O Relatório faz recomendações de conciliação, consenso, cooperação, solidariedade para enfrentar as tensões da mundialização, a perda das referências e de raízes, as demandas de conhecimento científico-tecnológico, principalmente das tecnologias de informação. A educação seria o instrumento fundamental para desenvolver nos indivíduos a capacidade de responder a esses desafios, particularmente a educação média. Sugere ainda a educação continuada e a certificação dos conhecimentos adquiridos (idem, p. 65-68).

Como co-patrocinador da Conferência de Jomtien, o Banco Mundial adotou as conclusões da Conferência, elaborando diretrizes políticas para as décadas subseqüentes a 1990 e publicando o documento Prioridades y estratégias para la educación, em 1995. Reitera os objetivos de eliminar o analfabetismo, aumentar a eficácia do ensino, melhorar o atendimento escolar e recomenda "a reforma do financiamento e da administração da educação, começando pela redefinição da função do governo e pela busca de novas fontes de recursos", o estreitamento de laços da educação profissional com o setor produtivo e entre os setores público e privado na oferta de educação, a atenção aos resultados, a avaliação da aprendizagem, a descentralização da administração das políticas sociais. Retoma, também, a teoria do capital humano por meio da inversão em 
capital humano e atenção à relação custo/benefício. A educação básica deveria ajudar a "reduzir a pobreza aumentando a produtividade do trabalho dos pobres, reduzindo a fertilidade, melhorando a saúde" e gerando atitudes de participação na economia e na sociedade (idem, p. 72-75).

Nesse contexto, na nova LDB que é aprovada no Governo Cardoso, a educação básica tem "por finalidades desenvolver o educando, assegurando-lhe a formação comum indispensável para o exercício da cidadania, e fornecer-lhe meios para progredir no trabalho e em estudos posteriores" (Lei no 9.394/96, art. 22) e organiza-se nos níveis fundamentais e médio (art. 24).

A segunda finalidade, expressa no art. 22 da Lei, fornecer ao educando "meios para progredir no trabalho e em estudos posteriores", apresenta-se como uma instância complementar à cidadania no sentido de realizar, pela educação, algumas das condições básicas para o exercício consciente da cidadania política. Neste sentido, a educação básica da escola brasileira depara-se com problemas que incorporam e ultrapassam o âmbito nacional e o escolar porque dizem respeito à história e à cultura do país e à reprodução econômica em todo o planeta, apesar de suas particularidades locais. Enfocaremos apenas os seguintes aspectos: a questão histórica da cidadania no Brasil, o domínio da cultura visual e a necessidade da educação tecnológica ou politécnica.

Historicamente, entendemos o problema da cidadania, no Brasil, como uma questão mal resolvida. A questão da cidadania é, originalmente, uma questão alheia à constituição da sociedade brasileira póscolonial, situação que teria se prolongado sob o fenômeno da exclusão dos "cidadãos" brasileiros de diversas instâncias da vida social. A questão que lhe está subjacente é sobre quem pertence à comunidade política e, por extensão, quem são os cidadãos e quais são os seus direitos de brasileiros. $^{3}$

A história do nascimento da Nação brasileira após a ruptura com o império colonial (Santos, 1978, p. 78-80), nos anos de 1822 a 1841 , foi crucial para a definição do tipo de sociedade que seria o Brasil. Para os liberais que conspiraram contra o regime colonial, o poder imperial deveria ser diminuído e a "sociedade brasileira" deveria governar o país. $\mathrm{O}$ que significava responder de onde emanava a fonte do poder político legítimo, se este deveria repousar sobre o centro de poder ou se o poder deveria ser delegado mediante mecanismos de representação política e social, quem estava qualificado para estas 
funções, quem pertencia à comunidade política como cidadão político pleno, para que serviam o governo e o Estado.

Não obstante o conhecimento do pensamento liberal (Locke, Montesquieu e a versão americana), o que prevaleceu se afastou do pacto liberal. O pacto constitucional apoiado pela elite brasileira estabeleceu que o poder imperial antecedia a criação da sociedade. $\mathrm{O}$ imperador era o Poder Moderador e todos os poderes (Legislativo, Judiciário e Executivo) e todos os ministros respondiam perante ele e não perante a comunidade política.

A questão sobre quem pertencia à comunidade política recebeu "nuances democráticas". A primeira interpretação excluía da comunidade política somente os criminosos, os estrangeiros e os religiosos. Mas, como o pacto político deveria expressar as igualdades e desigualdades existentes na sociedade que, no pensamento da época, eram naturais, definiu-se que os homens de posses eram os responsáveis pela riqueza do país e constituíam a comunidade política. O que se traduziu pelo critério censitário, de renda para distribuição dos direitos de voto. Posteriormente, com o voto obrigatório universal, ampliaram-se os direitos de votar e ser votado, sem que as condiçôes adequadas de vida, trabalho e educação tivessem se estendido, efetivamente, para toda a sociedade.

Mas a democracia, a cidadania, assim como os processos de incorporação de toda a população à sociedade produtiva, não se exercem em abstrato. Assistimos ao avultar dos problemas derivados do modelo político perverso das origens do país, agravados pelos desafios do desenvolvimento científico-tecnológico, das imposiçōes do mercado e de seus desdobramentos no nível da cultura.

Vivemos imersos em um mundo de altas tecnologias accessíveis na vida cotidiana e de informações abundantes, caóticas e dispersas, em que as imagens visuais prevalecem sobre a linguagem verbal, oral e escrita. Só muito lentamente vamos percebendo que se gerou uma nova sociabilidade e o que significa viver na "sociedade do espetáculo", tal como intuiu e teorizou Guy Débord nos anos de 1960. "O espetáculo não é um conjunto de imagens, mas uma relação social entre pessoas mediada por imagens." É uma visão de mundo que se materializou e não apenas o abuso da visão ou o produto de tecnologias sempre mais sofisticadas. É um resultado e um modo de produção da existência. Constitui o modelo atual de vida dominante na sociedade, sob todas as suas formas: informação, publicidade, televisão, filmes, vídeos, consumo de divertimentos. Não se trata apenas de novas linguagens, 
mas de uma nova forma de viver e de se inserir no mundo. "Toda a vida das sociedades nas quais reinam as modernas condições de produção se apresenta como uma imensa acumulação de espetáculos. Tudo o que era vivido diretamente se tornou representação" (Débord, 1997, p. 13-14).

Se a tese do autor faz sentido, não nos podemos espantar diante $\mathrm{da}$ inconsistência dos valores e comportamentos que regem a vida neste início de século. Há uma predominância da realidade fragmentada, como se toda ela fora feita de partes que se combinam e se desprendem para novas combinaçóes aleatórias, como é possível fazer com um conjunto de imagens fotográficas em que cada unidade é vista separadamente, abstraída do contexto que lhe dá o significado, que explica sua gênese e sua particularidade histórica.

O que está posto como desafio ao conhecimento e à ação é a fragmentação do mundo e sua reunificação ilusória na sedução da imagem. A escola, que sempre lidou com o discurso articulado do pensamento cognitivo, vê-se diante de novas formas de conhecer, aparentemente mais completas porque envolvem o sentimento, a emoção, o desejo. $\mathrm{Na}$ presença da cultura de tendência hegemônica do visual, a escola, supostamente, moderniza-se e incorpora acriticamente a imagem como ilustração, como motivação.

O que é um problema da cultura da sociedade se torna um problema de aprendizagem escolar. Não que o problema da aprendizagem não exista, mas ele não é reconhecido em todas as suas dimensões. Pensemos, por exemplo, no avançado desenvolvimento da ciência e na necessidade de uma educação tecnológica que responda às exigências de uma leitura atualizada do mundo. Ou pensemos na exaltação do mercado não apenas como o padrão das relações econômicas, mas de todas as relações humanas pela subsunção de tudo ao valor mercadoria. Pensemos na destruição do planeta pelo saqueio inconseqüente das formas de energia não-renováveis (o carvão, o gás, o petróleo), na fome destruidora de dois terços da humanidade e nos obstáculos para desenvolver um comportamento solidário entre os povos.

A base conceptual da educação básica em um novo projeto é, primeiro, o reconhecimento dos problemas maiores do mundo globalizado, sob os quais temos que tomar decisões locais. Em segundo lugar, assumir o direito inalienável do povo a uma escola pública de qualidade, que garanta a todos os cidadãos a satisfação da necessidade de um contínuo aprendizado. Neste sentido, a educação é tanto um direito social básico e universal quanto vital para romper com a histórica dependência científica, tecnológica e cultural do país, e fundamental 
para a construção de uma nação autônoma, soberana e solidária na relação consigo mesma e com outras nações. A educação é, portanto, ao mesmo tempo determinada e determinante da construção do desenvolvimento social de uma nação soberana. Além de ser crucial para uma formação integral humanística e científica de sujeitos autônomos, críticos, criativos e protagonistas da cidadania ativa, é decisiva, também, para romper com a condição histórica de subalternidade e de resistir a uma completa dependência científica, tecnológica e cultural.

\section{O projeto neoconservador do Governo Cardoso e a política de educação básica}

As análises críticas do período do Governo Fernando Henrique Cardoso (FHC) são abundantes tanto no âmbito econômico e político como no social, cultural e educacional. Todas convergem no sentido de que se trata de um governo que conduziu as diferentes políticas de forma associada e subordinada ${ }^{4}$ aos organismos internacionais, gestores da mundialização do capital e dentro da ortodoxia da cartilha do credo neoliberal, cujo núcleo central é a idéia do livre mercado e da irreversibilidade de suas leis.

Do ponto de vista econômico e social a síntese a que se chega é de que foi um período de mediocridade e de retrocesso. Francisco de Oliveira (2002), apoiando-se em dados de Reinaldo Gonçalves, indica que "além de ser medíocre, o período FHC tem sido o pior da história Republicana desde Prudente de Moraes” (p. 2). A avaliação de Perry Anderson (2002) dá-se na mesma direção.

A característica que define o governo FHC tem sido o neoliberalismo "light" do tipo que predominou nos anos 90 (...). A dinâmica fundamental do neoliberalismo se ergue sobre dois princípios: a desregulamentação dos mercados e a privatização dos serviços. (...) Fernando Henrique Cardoso leiloou a maior parte do setor estatal e abriu a economia completamente, apostando na entrada de um fluxo maciço de capital externo para modernizar o país. Após oito anos, os resultados estão aí, evidentes: estagnação crescente, salários reais em queda, desemprego em nível nunca antes visto e uma dívida estrondosa. O regime foi condenado aos seus próprios termos. (Anderson, 2002, p. 2)

A análise mais abrangente e contundente é de James Petras e Henry Velmeyer (2001) no livro Brasil de Cardoso: a desapropriação do Brasil, cuja tese central é a de que o governo de FHC governou para "tornar o 
Brasil seguro para o capital”. No campo da saúde e educação, áreas tidas pelo Governo FHC como de extraordinário avanço e alvos de intensa e permanente propaganda, segundo Oliveira, não se confirma "a melhoria dos seus indicadores; pelo contrário, procedimentos metodológicos que medem incrementos marginais dizem que houve uma desaceleração da melhoria" (op. cit., p. 2).

Uma análise de longa duração indica-nos que as políticas educacionais dos anos 90, em realidade, ganham compreensão mais ampla e profunda se as considerarmos como epílogo de três projetos societários do Brasil que "conviveram e lutaram entre si durante todo o século XX" (Fiori, 2002, p. 2). ${ }^{5}$

O primeiro projeto nasceu das idéias do liberalismo econômico, "mas sua formulação econômica e moderna foi dada pela política monetarista e ortodoxa e pela defesa intransigente do equilíbrio fiscal e do padrão-ouro, dos governos paulistas Prudente de Moraes, Campos Sales e Rodrigues Alves" (idem, ibid.). Ao longo do século XX é a concepção dominante incorporada pelos ministros da fazenda, C. Castro, Eugênio Gudin, Otávio Bulhões e Roberto Campos (no período da ditadura de 1964).

Este projeto, destaca Fiori, "foi o berço da estratégia econômica do Governo Cardoso" (idem, ibid.), cujo ministro, ao longo de dois mandatos, foi Pedro Malan. Projeto que sempre se contrapôs ao que Fiori denomina de "nacional desenvolvimentismo" ou "desenvolvimentismo conservador" presente na Constituinte de 1891 e nos anos de 1930. Mais enfaticamente se opunha a um terceiro projeto de "desenvolvimento econômico nacional e popular". Esta terceira alternativa "nunca ocupou o poder estatal, nem comandou a política econômica de nenhum governo republicano, mas teve enorme presença no campo da luta ideológicocultural e das mobilizações democráticas” (idem, p. 3).

Antes da denominada "era FHC" o Brasil experimentou uma década de intensos debates na travessia da ditadura civil-militar para a redemocratização. $\mathrm{O}$ centro desses debates foi canalizado pelo processo constituinte e, em seguida, pela elaboração da nova Constituição (1988). Poderíamos arriscar afirmar que o capítulo da ordem econômico-social incorporou amplas teses do projeto de desenvolvimento "nacionalpopular" e logrou ganhos significativos na afirmação de direitos econômicos, sociais e subjetivos.

É neste contexto que os educadores, mediante suas instituições científicas, culturais, sindicais e políticas, que resistiram no período 
ditatorial, protagonizam inúmeras experiências em prefeituras e depois em alguns estados, como demonstra detalhadamente Cunha (1991), e iniciam a construção do projeto da Nova Lei de Diretrizes e Bases da Educação Nacional e do Plano Nacional de Educação.

A travessia para a democracia, entretanto, ficou inconclusa. A vitória de Collor de Mello, filho das oligarquias nordestinas, muda a rota e assume o ideário ideológico que vinha se afirmando de todas as formas, mormente mediante as poderosas redes de informação, de que estávamos iniciando um "novo tempo". Este ajustamento pressupunha conter e restringir a esfera pública e efetivar-se de acordo com as leis da competitividade do mercado mundial.

Collor de Mello, todavia, revelou-se um fracasso. Tratava-se de uma solução política inesperada, expressão da incapacidade da classe dominante de construir um candidato dentro dos quadros políticos tradicionais. O impeachment, que ao final contou com o apoio até da poderosa Rede Globo de Comunicação, resultou da sua incapacidade política de afirmar um projeto de ajuste da sociedade brasileira à nova (des)ordem mundial sob o signo da mundialização do capital e dos setores internos a ela associados.

A burguesia brasileira encontra na figura de Fernando Henrique Cardoso a liderança capaz de construir seu projeto hegemônico de longo prazo, ao mesmo tempo associado e subordinado à nova (des)ordem da mundialização do capital. Com efeito, como analisa Francisco de Oliveira (1996 e 2001), a burguesia brasileira, pela primeira vez, busca um projeto de longo prazo, já que até o presente nossa história é uma sucessão de ditaduras e golpes institucionais.

Cardoso construiu um governo de centro-direita e, sob a ortodoxia monetarista e do ajuste fiscal, agora no contexto da férrea doutrina dos organismos internacionais e sua cartilha do Consenso de Washington, efetiva as reformas que alteram profundamente a estrutura do Estado brasileiro para "tornar o Brasil seguro para o capital". O fulcro deste projeto, como aludimos acima, é a doutrina neoliberal ou, mais apropriadamente, neoconservadora. Essa doutrina se baliza por alguns pressupostos que se constituem numa verdadeira bíblia desta nova hegemonia em construção em nível global, mas, com mais ênfase e destroços práticos, implanta-se em países como o Brasil.

O conjunto de pressupostos assumidos e partilhados pelo projeto econômico-social do Governo Cardoso é extraído da cartilha neoliberal do Consenso de Washington e pode ser resumido nos seguintes: 
primeiramente que acabaram as polaridades, a luta de classes, as ideologias, as utopias igualitárias e as políticas de Estado nelas baseadas. A segunda idéia-matriz é a de que estamos num novo tempo - da globalização, da modernidade competitiva, de reestruturação produtiva, de reengenharia -, do qual estamos defasados e ao qual devemos ajustarnos. Este ajustamento deve dar-se não mediante políticas protecionistas, intervencionistas ou estatistas, mas de acordo com as leis do mercado globalizado, mundial. ${ }^{6}$

O ajuste ou "concertación" traduz-se por três estratégias articuladas e complementares: desregulamentação, descentralização e autonomia e privatização. A desregulamentação significa sustar todas as leis: normas, regulamentos, direitos adquiridos (confundidos mormente com privilégios) para não inibir as leis de tipo natural do mercado. No caso brasileiro, para a reforma constitucional, a reforma da previdência e a reforma do Estado, o fulcro básico é de suprimir leis, definir bases de um Estado mínimo, funcional ao mercado.

A descentralização e a autonomia constituem um mecanismo de transferir aos agentes econômicos, sociais e educacionais a responsabilidade de disputar no mercado a venda de seus produtos ou serviços. Por fim, a privatização fecha o circuito do ajuste. $\mathrm{O}$ máximo de mercado e o mínimo de Estado. O ponto crucial da privatização não é a venda de algumas empresas apenas, mas o processo do Estado de desfazer-se do patrimônio público, privatizar serviços que são direitos (saúde, educação, aposentadoria, lazer, transporte etc.) e, sobretudo, diluir, esterilizar a possibilidade de o Estado fazer política econômica e social. O mercado passa a ser o regulador, inclusive dos direitos.

Desse ajuste resulta uma realidade perversa e cínica que Renato Janine Ribeiro (2000) sintetizou como sendo "a sociedade contra o social", onde "no discurso dos governantes ou no dos economistas a 'sociedade' veio a designar o conjunto dos que detêm o poder econômico, ao passo que o 'social' remete, na fala dos mesmos governantes ou dos publicistas, a uma política que procura minorar a miséria” (Janine, 2000, p. 19). Isso nos permite entender o protagonismo dos organismos internacionais, mormente do Banco Mundial e do Banco Interamericano de Desenvolvimento, nas reformas sociais e educacionais da última década.

Em seu conjunto, o projeto educativo do Governo Cardoso encontra compreensão e coerência lógica quando articulado com o projeto de ajuste da sociedade brasileira às demandas do grande capital. As demandas da sociedade organizada são substituídas por medidas 
produzidas por especialistas, tecnocratas e técnicos que definem as políticas de cima para baixo e de acordo com os princípios do ajuste. Cunha (1995), ao analisar as propostas educacionais dos candidatos Fernando Henrique Cardoso e Luiz Inácio da Silva (Lula), observava:

A plataforma de Lula resultou de um processo mais indutivo, de modo que segmentos de interesse social e partidário tiveram especial espaço nos documentos (negros, mulheres "profissionais da educação"), o que exigiu maior insistência nos princípios gerais, de modo que se mantivesse a unidade. (...) O documento de FHC foi elaborado por especialistas em planejamento governamental, razão pela qual se pôde selecionar as demandas que seriam incorporadas a partir das diretrizes gerais. (Cunha, 1995, p. 95)

E que especialistas foram estes? Na sua maioria, intelectuais altamente preparados em universidades do exterior e com passagem, alguns muito longa, outros mais breve, nos organismos internacionais que estão na base das reformas educativas: Banco Mundial, Banco Interamericano de Desenvolvimento, Organização Internacional do Comércio (OIT) etc. Esta lista é encabeçada com aquele que seria o ministro de Educação de FHC por oito anos, Paulo Renato Souza, e completada, entre outros, por João Batista de Araújo, Cláudio de Moura Castro, Guiomar Namo de Melo e Maria Helena Guimarães Castro.

E quais as demandas e que grupos foram beneficiados no campo educativo? Sem dúvida aqueles grupos que estão articulados historicamente com o metabolismo do capital dos centros hegemônicos neste novo contexto de sua mundialização. É o Governo Cardoso que, pela primeira vez, em nossa história republicana, transforma o ideário empresarial e mercantil de educação escolar em política unidimensional do Estado. Dilui-se, dessa forma, o sentido de público e o Estado passa a ter dominantemente uma função privada. Passamos assim, no campo da educação no Brasil, das leis do arbítrio da ditadura civil-militar para a ditadura da ideologia do mercado (Frigotto, 2002).

José Rodrigues (1988) evidencia-nos que os empresários, por intermédio de seus organismos de classe, especialmente desde os anos de 1930, disputavam a hegemonia de seu pensamento educacional não só no âmbito da formação e qualificação profissional, mas, mais amplamente, da educação escolar. Trata-se de ajustar a educação escolar que serve à reestruturação produtiva e às mudanças organizacionais e a base técnico-científica à nova divisão internacional do trabalho. Este intento nem mesmo no período da ditadura civil-militar foi atingido. Isso vai ocorrer de forma explícita e orgânica no Governo Cardoso. 
Em diferentes análises, Neves (1994, 1995, 1999, 2000a, 2000b e 2002) efetiva um detalhado exame das políticas educacionais das décadas de 1980 e 1990 e de quais os determinantes estruturais e conjunturais, dentro da nova ordem mundial, que nos permitem entender a presença dominante do pensamento empresarial na educação no Brasil.

O projeto de educação básica do Governo Cardoso afirma-se sob a lógica unidimensional do mercado, explicitando-se tanto no âmbito organizativo quanto no do pensamento pedagógico. Como as idéias de um projeto de desenvolvimento "nacional popular" e autônomo passaram a ser ridicularizadas, também o foi a perspectiva de uma educação básica omnilateral, politécnica ou tecnológica (Saviani, 2003).

A ausência de uma efetiva política pública, com investimentos no campo educacional, compatíveis com o que representa o Brasil em termos de geração de riqueza, vai conduzindo a medidas paliativas que reiteram o desmantelamento da educação pública em todos os seus níveis. Uma das estratégias utilizadas por alguns estados para diminuir os custos na educação básica tem sido a utilização do teleensino, mediante compra de pacotes do Telecurso 2000 da Rede Globo de Televisão.?

A dimensão talvez mais profunda e de conseqüências mais graves situa-se no fato de que o Governo Fernando H. Cardoso, por intermédio do Ministério da Educação, adotou o pensamento pedagógico empresarial e as diretrizes dos organismos e das agências internacionais e regionais, dominantemente a serviço desse pensamento como diretriz e concepção educacional do Estado. Trata-se de uma perspectiva pedagógica individualista, dualista e fragmentária coerente com o ideário da desregulamentação, flexibilização e privatização e com o desmonte dos direitos sociais ordenados por uma perspectiva de compromisso social coletivo. Não é casual que a ideologia das competências e da empregabilidade $^{8}$ esteja no centro dos parâmetros e das diretrizes educacionais e dos mecanismos de avaliação.

Maria H. Guimarães Castro, secretária da Secretaria de Ensino Superior (SESU) do Ministério da Educaçăo (MEC) e diretora do Instituto Nacional de Estudos e Pesquisas Educacionais (INEP), responsável pela Avaliação Nacional do Ensino Superior (Lei no 9.131, o "Provão"), pelo Exame Nacional do Ensino Médio (ENEM) e pelo Sistema Nacional de Avaliação da Educação Básica (SAEB), ${ }^{9}$ explicita claramente que as competências que devem ser avaliadas são aquelas que os empresários indicam como desejáveis. 
Em uma pesquisa recente realizada pelo MEC, sobre o que o mercado de trabalho esperava dos alunos ao final do Ensino Médio de cursos profissionalizantes, revelou-se que as empresas querem que esses estudantes tenham domínio de Língua Portuguesa, saibam desenvolver bem a redação e se comunicar verbalmente. Esta é uma das competências gerais que o ENEM procura avaliar e que a Reforma do Ensino Médio procura destacar. Em segundo lugar, os empresários querem que os futuros trabalhadores detenham os conceitos básicos de matemática e, em terceiro lugar, que tenham capacidade de trabalhar em grupo e de se adaptar a novas situaçôes. Portanto o que os empresários estão esperando dos futuros funcionários são as competências gerais que só onze anos de escolaridade geral podem assegurar. (Castro, 2001; grifos nossos)

A afirmação de Castro não acrescenta, todavia, que essas competências gerais vêm demarcadas pela perspectiva unidimensional daquilo que "serve para o mercado". ${ }^{10}$ Fica patenteado que a análise de Rodrigues (1998) sobre a disputa dos empresários pela hegemonia do pensamento pedagógico para além da formação profissional específica materializa-se no Governo Cardoso. Isso corrobora as análises de Neves (2002) sobre a reprodução do trabalho simples e adaptação ao complexo na divisão internacional do trabalho, e as análises de Giovani Arrighi (1998) que mostram que países semiperiféricos, como o Brasil, desenvolvem as atividades neuromusculares, ao passo que os países do capitalismo orgânico central desenvolvem as atividades cerebrais.

\subsection{A LDB minimalista e a face privada do Conselho Nacional de Educação}

A estratégia do Governo Cardoso de subordinar as reformas educativas, no plano organizativo e pedagógico, ao projeto de ajuste econômico-social fica evidente já pela repulsa ao projeto de LDB construído a partir de mais de 30 organizaçóes científicas, políticas e sindicais, congregadas no Fórum Nacional em Defesa da Escola Pública. Sua estratégia aprofunda-se pela natureza e composição do Conselho Nacional de Educação.

O infindável processo de tramitação da LDB e as centenas de emendas e destaques ${ }^{11}$ feitos pelos parlamentares da base de governo, em verdade, eram uma estratégia para ganhar tempo e ir implantando a reforma educacional por decretos e outras medidas. O pensamento dos educadores a sua proposta de LDB não era compatível com a ideologia e com as políticas do ajuste e, por isso, aqueles foram 
duramente combatidos e rejeitados. Foi por isso, também, que o projeto de LDB oriundo das organizaçóes dos educadores, mesmo sendo coordenado, negociado e desfigurado pelos relatores do bloco de sustentação governamental, foi rejeitado pelo governo. Todas as decisões fundamentais foram sendo tomadas pelo alto, pelo Poder Executivo, por meio de medidas provisórias, decretos ou por leis conquistadas no Parlamento mediante o expediente da troca de favores.

A demora do governo para aprovar projeto substitutivo do senador Darcy Ribeiro, que desfigurava o projeto dos educadores que tramitava na Câmara, também nada teve de inocente. Tratava-se de uma estratégia para, ao mesmo tempo, ir transformando esse substitutivo em projeto adequado aos interesses do governo e ir impondo sua política de ajuste pontual e tópico no campo educacional.

A Lei de Diretrizes e Bases (Lei no 9.394/96), finalmente aprovada pelo Congresso, resultou da iniciativa personalista do senador Darcy Ribeiro e representou, para Florestan Fernandes (1991) uma dupla traição: fez uma síntese deturpada do longo processo de negociação do projeto negociado com a sociedade organizada e deu ao governo, que não tinha projeto de LDB, o que este necessitava. Coerentemente, então, como evidencia Saviani, em minuciosa análise dos projetos de LDB em disputa, deveria ser uma LDB minimalista e, portanto, em consonância com a proposta de desregulamentação, de descentralização e de privatização e “compatível com o Estado Mínimo” (Saviani, 1997, p. 200).

Poderíamos dizer, sem exagero, que a nova LDB é uma espécie de ex-post cujo formato, método de construção e conteúdo se constituem em facilitador para medidas previamente decididas e que seriam, de qualquer forma, impostas. Exemplar, neste particular, como veremos adiante, é o que veio a se denominar de educação profissional. Apesar de a LDB já dar as diretrizes, o Decreto no 2.208 de 1997, que é uma cópia quase fiel do Projeto de Lei no 1.603/96, veio regulamentar a Lei, embora tenha encontrado ampla resistência, no Parlamento, mediante a pressão das organizações que compunham o Fórum Nacional em Defesa da Escola Pública.

Durante os anos da ditadura e na transição, um dos espaços profundamente comprometidos e envolvidos em negociatas com os grupos do privatismo foi o Conselho Federal de Educação. Ao longo dos anos constituiu-se como uma espécie de câmara de troca de favores junto ao Ministério da Educação, concebido como um órgão da Administração Federal e subordinado ao Poder Executivo. Por isso, no contexto do amplo movimento de redemocratização da sociedade brasileira, a natureza e a 
composição do Conselho Federal de Educação foi alvo de intensos debates. Como reflexo disto, o projeto de LDB apresentado na Câmara pelo deputado Otávio Elísio, em 1988, propunha um Conselho Nacional de caráter deliberativo e legislativo com autonomia econômica, financeira e administrativa. Este teria uma composição com a indicação de um terço pelo ministro da Educação, um terço pela Câmara Federal e um terço pelas entidades representativas do magistério. $\mathrm{O}$ mesmo espírito foi mantido pelo substitutivo Jorge Hage e aprovado na Câmara. Tratava-se de um extraordinário avanço.

Esta perspectiva autônoma do Conselho e a forma democrática de sua composição se confrontam com as diretrizes gerais da conformação da educação ao ajuste estrutural proposto pelo governo no âmbito das reformas do Estado. O substitutivo do senador Darcy Ribeiro, como demonstra Saviani (op. cit., p. 207), não fazia nenhuma menção ao Conselho e, na tramitação, fez-se uma referência no inciso IX do artigo $9^{\circ}$, mantido na versão final aprovada e sancionada, que diz: " $\mathrm{Na}$ estrutura educacional, haverá um Conselho Nacional de Educação, com funções normativas e de supervisão e atividade permanente, criado por lei”. Esta formulação, como bem analisa Saviani, permitiu manter o Conselho Nacional de Educação tutelado e sob o controle do Executivo e, portanto, em direção oposta ao projeto aprovado pela Câmara Federal em que o "CNE tinha um outro caráter: era uma instância com funções deliberativas no âmbito da educação análogas àquelas exercidas pelo Legislativo e Judiciário no âmbito da sociedade como um todo" (idem, p. 208).

Prevalecendo o caráter consultivo do CNE e sob a égide do MEC, ao longo dos oito anos de mandato do Governo Cardoso o ministro Paulo Renato Souza nomeou os conselheiros em número mais que suficiente para que nada, que fosse fundamental ao projeto educativo preconcebido, escapasse do seu controle. $\mathrm{Na}$ primeira composição foram incluídos alguns nomes sugeridos pelas entidades do magistério, mas sem força suficiente para além de retardar ou dificultar algumas medidas. No segundo mandato do ministro (1998-2002), o CNE, reeditando o passado, foi espaço de legitimação do projeto mercantilista e privatista do Governo Cardoso.

\subsection{O Plano Nacional de Educação: projetos em disputa}

Os planos nacionais de educação destinam-se a regulamentar a lei nacional de educação em termos de traduzir a política educacional 
em vigor em estratégias de cumprimento da lei. Esse procedimento supõe uma ampla negociação com a sociedade e com o Legislativo de modo que se garanta a orientação política da lei por meio da destinação efetiva de recursos e da elaboração de instrumentos legais complementares. No Brasil, onde a tradição autoritária suplanta, freqüentemente, os procedimentos democráticos, os planos educacionais aproximam-se da política e assumem sua feição mais genérica, ficando a salvo do cumprimento de metas definidas em função dos problemas a resolver.

As políticas e os planos educacionais, implementados em nível do Estado, no Brasil, acompanham as vicissitudes da sociedade brasileira na falência de não consolidar, até hoje, uma sociedade democrática e de não incorporar amplos setores populares a um projeto superior de país. ${ }^{12}$

Os planos nacionais de educação, num primeiro momento da vida nacional, adquirem o sentido de lei e se aproximam das políticas educacionais em gestação (anos 20 e 30). Num segundo momento eles são vistos como uma parte do planejamento estabelecido e refletem a relação educação e desenvolvimento econômico (a partir do final dos anos 40).

Neste sentido, ou a idéia de plano nacional de educação esvazia-se e o plano assume o sentido restrito de plano de aplicação de recursos (na LDBEN no 4.024 de 1961) ou assume a forma de um plano de governo contendo metas qualitativas e quantitativas que vão subsidiar os planos posteriores. Os planos subseqüentes a 1964 saem gradativamente do âmbito dos pedagogos, para os tecnocratas, economistas e engenheiros da "nova" economia nacional dos anos 70 que se prolongou até a década atual (Horta, 1982 e 1997). ${ }^{13}$

$\mathrm{O}$ atual Plano Nacional de Educação (PNE), na forma da Lei no 10.172 de 9/1/2001, é uma resposta autocrática do Governo Cardoso (1994-2002) ao Plano Nacional da Educação da Sociedade Brasileira, elaborado sob a liderança do Fórum Nacional em Defesa da Escola Pública, que também conduziu a elaboração do projeto da Lei de Diretrizes e Bases da Educação Nacional, a partir de 1986, juntamente com a Constituinte de $1988 .{ }^{14}$ O que se deu por intermédio de inúmeros encontros preparatórios e seminários temáticos, nos diversos pontos do país. O deputado federal Ivan Valente analisa os dois projetos em disputa como dois projetos de Brasil (Valente, 2001). O projeto governamental foi orientado pelo centralismo de decisões, da formulação e da gestão da política educacional, principalmente na esfera federal. Pauta-se pelo progressivo abandono, por parte do Estado, das tarefas de manutenção e desenvolvimento do ensino, por meio de mecanismos de 
envolvimento de pais, organizações não-governamentais, empresas e de apelos à "solidariedade" das comunidades onde se situam as escolas e os problemas. $\mathrm{O}$ que resultou em parâmetros privatistas para o funcionamento dos sistemas de ensino.

$\mathrm{O}$ projeto da sociedade brasileira reivindicava e continua a reivindicar o fortalecimento da escola pública estatal e a democratização da gestão educacional "como eixo do esforço para universalizar a educação básica" (fundamental e média) e, progressivamente, o ensino superior. $\mathrm{Na}$ prática, significaria passar do investimento de $4 \%$ do PIB em educação para $10 \%$ ao final de dez anos de PNE.

A resposta governamental, quando trata da competência da União, contorna "a necessidade de indicar prazos e de apontar o setor competente pela execução da meta, contrariamente ao sentido, muitas vezes invasivo, com que normatiza condutas e procedimentos aos estados e municípios" e procede "à transferência de responsabilidades da União aos entes subnacionais, como tentativa de remediar os males decorrentes de açōes anteriores do governo federal", como é o caso do Fundo de Manutenção e Desenvolvimento do Ensino Fundamental e de Valorização do Magistério (FUNDEF) (Davies, 1999, p. 11-12 e 35). ${ }^{15}$

Para o movimento civil organizado, que defendeu o PNE, o Presidente FHC "veta o que faria do PNE um plano" e comunica os vetos ao Parlamento (Mensagem no 9 de 9/1/2001) informando que "quem orientou a imposição dos vetos ao PNE foi a área econômica do governo, através dos Ministérios do Planejamento e da Fazenda", o que significa, de modo especial, "as razões da política ditada pelo FMI" (Valente, 2001, p. 37). A retração do Estado e a privatização dos serviços, ao contrário do discurso oficial e publicitário, não trouxeram benefícios à população. Ao contrário, privatizaram e elitizaram os serviços, transferiram o clientelismo populista para o clientelismo junto às organizações da sociedade civil e introduziram o voluntariado como uma questão de "cidadania". São políticas que visam a minorar os efeitos da expropriação econômica e cultural que atingem as classes assalariadas (subempregados e desempregados), marginalizados, em diversos níveis, dos benefícios sociais propiciados pelo desenvolvimento das forças produtivas. São políticas pobres para os pobres. ${ }^{16}$

\subsection{A educação fundamental e os Parâmetros Curriculares Nacionais}

A política de ensino fundamental, no seu âmbito organizativo e pedagógico, foi eleita como prioridade central dos oito anos do Gover- 
no Cardoso. Como assinalamos acima, não houve uma efetiva melhora em seus indicadores básicos. Em estudo recente, Davies (2003) aponta discrepâncias nas análises estatísticas do Ministério da Educação e questiona a campanha de 1997/1998, “Toda criança na escola”, que teria sido viabilizada pelo FUNDEF. ${ }^{17}$

Com efeito, a educação infantil, a educação de jovens e adultos, a educação de nível médio e superior ficaram relegadas a iniciativas tópicas. A educação infantil, ou de 0 a 6 anos, foi delegada aos governos municipais ou às famílias, com a penalização da classe trabalhadora. A educação de jovens e adultos passou a se reduzir às políticas de formação profissional ou requalificação deslocada para o Ministério do Trabalho ou para iniciativas da sociedade civil. Na educação média, a política foi de retroceder ao dualismo estrutural entre o ensino médio acadêmico e técnico. No nível superior apostou-se deliberadamente na expansão desenfreada do ensino privado. ${ }^{18} \mathrm{Um}$ aumento de $80 \%$ nos oito anos do Governo Cardoso, sendo que aproximadamente $76 \%$ no nível privado. Em alguns estados da União, como no caso do Rio de Janeiro, houve um decréscimo na oferta do ensino superior público de 2,6\%.

Em que sentido se pode afirmar que o resultado da prioridade do ensino fundamental foi pífio? Como indicamos no item 2, a concepção organizativa e pedagógica do projeto educativo do Governo Cardoso funda-se nos critérios mercantilistas, economicistas e, portanto, num caráter instrumental. $\mathrm{O}$ dogma de não comprometer o ajuste fiscal não poupou a prioridade do ensino fundamental. $\mathrm{O}$ governo aumentou as estatísticas de acesso, ${ }^{19}$ o que é um dado positivo, mas insuficiente, pois degradou as condições de democratização do conhecimento.

A análise criteriosa feita por Saviani dos projetos de LDB da Câmara, do Senado e da lei aprovada sinaliza um aspecto muito sutil, mas revelador de que o Governo Cardoso não queria comprometer-se com mais gastos na educação fundamental. A LDB aprovada restringiu, no Direito, Dever e Liberdade de Educar, o preceito constitucional que diz: "O acesso ao ensino obrigatório e gratuito é direito subjetivo" (art. 208, inciso VII, parágrafo I). Na LDB está escrito: "o acesso ao ensino fundamental é direito publico subjetivo” (art. 50) (Saviani, 1997, p. 203). Para Saviani, esta restrição tanto abre a possibilidade de o governo não se obrigar à gratuidade como pode ter sido uma medida preventiva para não estender a obrigatoriedade e a gratuidade ao nível médio de ensino, as quais haviam sido aprovadas no projeto da Câmara, elaborado com intensa participação do Fórum Nacional em Defesa da Escola Pública. 
O não-comprometimento efetivo com a melhoria da educação fundamental se manifesta pela descentralização autoritária dos encargos de manutenção da educação infantil e fundamental pelos municípios sem garantir, em sua maioria, condiçōes mínimas de manter um atendimento qualitativo. Com a criação do Fundo de Manutenção e Desenvolvimento do Ensino Fundamental e de Valorização do Magistério (FUNDEF) para permitir um gasto mínimo aluno/ano no ensino fundamental, os municípios aceleraram o processo de incorporação das matrículas depois que perceberam que poderiam, com isso, aumentar suas receitas compulsórias. Em certos casos houve matrículas fantasmas. ${ }^{20}$

O FUNDEF, todavia, funcionou como uma espécie de condomínio onde o governo federal induz a transferência dos estados aos municípios e centraliza outros recursos e os redistribui para os que não atingem o teto mínimo, menos de 400 reais aluno/ano. Isso se confirma pelas conclusóes a que chega José M. de Rezende Pinto:

O governo federal divulga relatórios róseos sobre os efeitos do Fundo (MEC, 1999), curiosamente, divulgando apenas os ganhos de receitas dos municípios, sem mostrar que estes recursos "ganhos" correspondem exatamente às quantias perdidas pelas redes estaduais, mesmo porque os recursos adicionais federais são ínfimos (menos de 3\% dos recursos do Fundo). (...) Portanto, nos anos FHC, apesar de o país ter vivido um progressivo aumento da carga tributária, esta melhoria de arrecadação não repercutiu no sentido de ampliar efetivamente os gastos com ensino no Brasil. (Pinto, 2002, p. 117 e 128$)^{21}$

O fraco investimento efetivo na educação fundamental soma-se não na valorização que o FUNDEF preconiza na própria sigla, mas na desvalorização do magistério. As apelativas e seqüenciais campanhas de "adote uma escola", "amigos da escola", "padrinhos da escola" e, depois, do "voluntariado" explicitam a substituição de políticas públicas efetivas por campanhas filantrópicas. No âmbito organizativo e institucional, a educação básica, de direito social de todos, passa a ser cada vez mais encarada como um serviço ou filantropia. Com isso se passa a imagem e se instaura uma efetiva materialidade de que a educação fundamental não é dever do Estado e espaço para profissionais especializados e qualificados, mas para ações fortuitas e tópicas de amigos, padrinhos e de voluntários. Os professores foram sendo prostrados por uma avalanche de imposições, reformas sobre reformas e mudanças sobre mudanças, humilhados nas suas condições de vida e de trabalho e ignorados e desrespeitados no seu saber e profissão. 
No plano pedagógico duas políticas do governo federal no ensino fundamental - os Parâmetros Curriculares Nacionais (PCNs) e a avaliação (SAEB) - explicitam, ao mesmo tempo, o caráter dedutivo e, pelo alto das propostas educacionais do Governo Cardoso, apontadas acima por Cunha, a sua perspectiva economicista e mercantilista.

Esta característica de definição pelo alto não só se contrapôs a lutas históricas e a inúmeros estudos construídos com base na realidade sociocultural e econômica do país, mas na forma em que se realiza está repleta de incongruências. Por diferentes ângulos as análises de Edith Frigotto, Lucíola L. de P. C. Santos e de Alicia Bonamino e Silvia A. Martinez realçam estas contradições e seus efeitos imobilizadores que interferem negativamente sobre os processos de construção do conhecimento.

Para Edith Frigotto (1999), o governo proclama a importância de as escolas produzirem, dentro de suas realidades e de forma participativa, seus currículos e propostas político-pedagógicas. Essas propostas, todavia, vêm sendo atropeladas por diferentes mecanismos e exigências que transformam, na prática, os PCNs, produzidos por especialistas e consultores distanciados das condiçôes concretas da realidade brasileira, numa imposição obrigatória. A autora destaca como mecanismos que induzem ao constrangimento obrigatório, entre outros, o Sistema Nacional de Avaliação da Educação Básica (SAEB), montado a partir dos PCNs, a política do livro didático e a formação nacional dos professores da educação básica em serviço.

Lucíola L. de P. C. Santos (2002), numa mesma perspectiva de análise, mostra que a concepção dos PCNs, tal qual foi proposta, apresentase inviável, tanto do ponto de vista da natureza do processo de construção curricular, que implica constante construção e reconstrução a partir de realidades concretas, quanto das condiçôes objetivas de sua realização e avaliação. A pesquisadora pergunta:

Como implementar os parâmetros Curriculares Nacionais se os professores têm que resolver problemas sociais, restando pouco tempo para conteúdos educacionais previstos naquela proposta? Qual a finalidade do SAEB se já sabemos que não existe na escola espaço para o desenvolvimento dos conteúdos acadêmicos nas formas como são propostos? Como formar um superprofissional da educação, capaz de lidar com problemas tão complexos, se a carreira do magistério é tão pouco atrativa do ponto de vista salarial e profissional? (Santos, 2002, p. 368)

O caráter alheio dos PCNs, feitos pelo alto, aos processos e às mediaçôes complexas constitutivas das realidades socioculturais onde se 
efetivam os sistemas municipais de educação ratifica-se de forma emblemática no fato de, como mostram Alicia Bonamino e Silvia A. Martinez, o Ministério da Educação ignorar os estudos e as próprias Diretrizes Curriculares Nacionais produzidas pelo Conselho Nacional de Educação. Para as autoras o processo de constituição dos PCNs pelo MEC e das Diretrizes Curriculares Nacionais (DCNs) pelo CNE estabeleceu uma inversão e uma omissão mútua. "Percebemos que se tratava de uma política construída num movimento invertido, no qual os PCNs, apesar de serem instrumentos normativos de caráter mais específico, foram construídos e encaminhados de forma a reorientar um instrumento de caráter mais geral como as DCNs" (Bonamino \& Martinez, 2002, p. 385). A inversão a que se referem é coerente com a decisão do Executivo de impor à sociedade um Conselho Nacional de Educação consultivo e subordinado ao MEC e não um Conselho, como analisamos acima, autônomo e deliberativo.

O Sistema Nacional de Avaliação da Educação Básica (SAEB) ${ }^{22}$ constitui-se em mais um instrumento coercitivo, também produzido pelo alto, e que tem um efeito desagregador e inócuo se consideramos os aspectos acima apontados por Santos (op. cit.). O que o MEC recolhe são dados que, se efetivamente analisados como o faz uma pesquisa da Confederação Nacional dos Trabalhadores em Educação, acabariam reprovando o conjunto de políticas do próprio Ministério. ${ }^{23}$ Trata-se de uma avaliação que não avalia as condiçôes de produção dos processos de ensino e que não envolve diretamente o corpo docente, portanto não é avaliação e sim uma mensuração simples. A forma de divulgação e o uso desta "medida" como avaliação punitiva pelo Ministério da Educação ou a sua utilização seletiva como critério de acesso ao nível superior e ao emprego ampliam as suas deformaçôes. Ressaltamos que não se trata de negar o direto e o dever do Estado de avaliar, o que está em questão é o método, o conteúdo e a forma autoritários e impositivos de sua implementação.

\subsection{A reforma da educação média e técnica e a emergência da educa- ção tecnológica ${ }^{24}$}

No final dos anos 70, algumas das mais renomadas Escolas Técnicas Federais (Minas Gerais, Paraná e Rio de Janeiro, e mais tarde, durante o Governo Sarney, Bahia e Maranhão) transformam-se em Centros Federais de Educação Tecnológica - CEFETs - (Lei no 6.545 de 30/6/1978). ${ }^{25} \mathrm{O}$ que significava passar a oferecer não apenas educação 
de nível médio técnico, mas também cursos de nível superior (graduação e pós-graduação em engenharia industrial e tecnólogos, licenciaturas plena e curta nas áreas de formação de professores e especialistas, cursos de extensão, especialização e aperfeiçoamento, e pesquisas na área técnicoindustrial - art. $2^{\circ}$ ). Na prática, o governo do general Ernesto Geisel dava uma nova função às escolas que ministravam cursos de engenharia de operação, naquele momento em situação delicada porque a procura maior era a engenharia plena das universidades.

A “educação tecnológica” pode ter sido apenas mais um novo nome para a realidade que se desejava criar. No entanto o desenvolvimento científico-tecnológico, que fazia parte do ideário nacionaldesenvolvimentista dos militares no poder desde 1964, era uma realidade em expansão no mundo ocidental.

Nas últimas décadas, o desenvolvimento científico-tecnológico responde por um novo fator fundamental: disponibilidade ampla da microeletrônica e baixos custos no processamento da informação. Toma força um processo de profunda reestruturação do aparato produtivo com a incorporação de tecnologias intensivas em informação com base na microeletrônica (Ciavatta, 2002, p. 60). Eleva-se a composição técnica do capital e altera-se a divisão internacional do trabalho, sua divisão social, sexual e de reprodução humana (Gitahi \& Rabelo, 1997). Surge um novo perfil ocupacional no qual é sensível o aumento dos requisitos educacionais para o mercado formal. Há uma progressiva substituição da força física pelas "capacidades intelectuais".

Esta é a base do que Adam Schaff (1990) chamou de "sociedade informática”, assinalando tendências, hoje, em grande parte realizadas, tais como sociedade do tempo livre/sociedade do desemprego, qualificação/desqualificação, centralização/descentralização, autonomia/ controle etc. É o que hoje se denomina "sociedade do conhecimento", cujas análises destacam a nova sociabilidade do capital. $\mathrm{Na}$ competição entre os capitais e na subordinação do trabalho ao capital, essas análises elidem a questão das classes sociais. Neste contexto, no plano políticoideológico, ganham divulgação as teses da sociedade pós-industrial, pós-capitalista, pós-moderna, sociedade sem classes, fim da história, fim das ideologias, interpretaçôes parciais de processos complexos, teses que não revelam seus interesses particulares e sua própria ideologia.

Neste trabalho, consideramos que o projeto educacional, em seu conjunto, não pode estar desvinculado do projeto social mais amplo. ${ }^{26}$ Antes, deve estar articulado às políticas de desenvolvimento econômico 
locais, regional e nacional; às injunçôes do desenvolvimento científicotecnológico; às políticas de geração de emprego, trabalho e renda, juntamente com aquelas que tratam da formação e da inserção econômica e social da juventude. Supóe que se mobilize a capacidade produtiva nacional em favor do crescimento, aproveitando toda a capacidade técnica, empreendedora e criadora do povo.

A reforma educacional praticada pelo Governo FHC, no seu conjunto e, em particular, em relação à educação tecnológica e à formação profissional, foi coerente com o ideário do liberalismo conservador em termos econômicos e sociais, tanto na concepção quanto na ação prática. O Decreto $n^{\circ}$ 2.208/97 é uma síntese emblemática desse ideário. Esse decreto foi complementado, como instrumento coercitivo, pela Portaria do MEC no 646 de 1997, que obriga os Centros Federais de Educação Tecnológica a restringirem em $50 \%$ as matrículas do nível médio integrado, das oferecidas em 1966, com o indicativo de extensão futura. A arma do MEC para isso era a concessão de mais ou menos recursos de acordo com a adesão à portaria. No plano pedagógico, a Resolução no $04 / 99$ e o Parecer CNE/CEB no 16/99, que traçam as Diretrizes Curriculares Nacionais para os cursos técnicos de nível médio, escancaram a perspectiva economicista, mercantilista e fragmentária mediante a pedagogia das competências e a organização do ensino por módulos, sob o ideário da ideologia da empregabildiade.

Ele reinstaura uma nova forma de dualismo na educação ao separar a educação média da educação técnica. Por isso ele é incompatível, teoricamente e em termos de ação política, com um projeto democrático de educação adequado ao baixo nível de escolaridade básica e de formação profissional da população economicamente ativa, no sentido de superar essa realidade.

Ainda não há um acúmulo de conhecimento para se saber, exatamente, os termos de implantação da reforma nos CEFETs a partir do Decreto $\mathrm{n}^{\circ}$ 2.208/97. Algumas instituiçôes aderiram ao projeto do governo. Outras estudam sua adaptação. A Câmara de Ensino do Conselho de Diretores dos CEFETs (CONCEFET) e o Fórum de Diretores de Ensino dos CEFETs, a partir do projeto pedagógico implementado nas instituiçōes federais de educação tecnológica, elaboraram um documento onde registram "um novo modelo pedagógico pautado no desenvolvimento de currículos por competências". ${ }^{27}$ De outra parte, defendem que "a educação tecnológica deve abranger todas as dimensões da vida e desenvolver todas as potencialidades científicas, sociais, políticas e culturais", sinalizando que isso "ultrapassa os limites do 
ensino tradicionalmente chamado técnico, ao integrar o saber e o fazer" e a reflexão sobre significado destas ações em uma sociedade em que os valores humanos estão em transformação (Conselho, 2002).

Coerentemente com as reflexões e experiências teórico-políticas de especialistas e trabalhadores da educação em todos os níveis do sistema educacional no país, acumuladas historicamente, cabe a defesa de uma escola unitária, que supere o dualismo da organização social brasileira, com conseqüências para a organização do sistema educacional. O que significa a superação definitiva da concepção que separa a educação geral, propedêutica, da específica e profissionalizante, a primeira destinada aos ricos, e a segunda, aos pobres. Essa perspectiva não admite subordinar a política educacional ao economicismo e às determinações do mercado, que a reduz aos treinamentos para preenchimento de postos de trabalho transitórios. Isso supóe recuperar, no plano conceitual, o debate da concepção de educação tecnológica ou politécnica, fundamental na orientação da educação básica e, em especial, do ensino médio das escolas técnicas federais e estaduais e dos Centros Federais de Educação Tecnológica. Por essa concepção, a educação básica estrutura-se em consonância com o avanço do conhecimento científico e tecnológico, fazendo da cultura técnica um componente da formação geral, articulada com o trabalho produtivo. Isso pressupõe a vinculação da ciência com a prática, bem como a superação das dicotomias entre humanismo e tecnologia, e entre formação teórica geral e técnica instrumental.

\section{Considerações finais: da resistência ativa à urgência de inverter a direção}

A direção da análise que empreendemos neste artigo corrobora inúmeras outras análises, de caráter mais abrangente, algumas aqui referidas, de que a subordinação consentida aos organismos internacionais, tutores dos interesses do grande capital, a participação ativa nesses organismos e a adoção das políticas neoliberais veiculadas por eles aumentaram no Brasil a desigualdade. A cidadania, como conquista na direção política da solução dos problemas nacionais, é mais uma palavra que encobre o fenômeno da exclusão dos "cidadãos" brasileiros de diversas instâncias da vida social, a exemplo da educação. A fragmentação do conhecimento, a informação/desinformação da cultura visual aumentaram a versatilidade da propaganda oficial sobre os supostos benefícios do neoliberalismo. A formação dos jovens para a apropriação criativa da ciência e da tecnologia debate-se entre uma reforma imposta ao ensino 
médio e técnico com forte acento nos cursos breves, modularizados para a crença na "empregabilidade".

O Governo Cardoso deixa de herança uma enorme dívida social com o agravamento de todos os indicadores sociais - "o pior período na história republicana desde Prudente de Moraes" -, como demonstram as análises de Francisco de Oliveira e Perry Anderson acima sinalizadas.

Concordamos com a análise de Sader (2002) de que "foi o fracasso do neoliberalismo tardio de Cardoso que propiciou o favoritismo de Lula nas eleições de 2002". A vitória das forças políticas e sociais, e dentre estas, de uma maioria que efetivou resistência ativa tanto à ditadura "civilmilitar" quanto à ditadura do capital mediante as políticas neoliberais, tem a tarefa e o compromisso ético-político de uma inversão de direção primeiramente do modelo econômico, condição de mudanças concomitantes na esfera social e educacional. Mas é bom que se tenha presente que a herança Cardoso, paradoxalmente, em seus efeitos de compromissos, acordos e "dogmas" institucionais, perdura como uma esfinge a ser decifrada pelo atual governo ou este será por ela devorado.

Em face desta herança, o novo governo precisa, como exorta Celso Furtado, "de muita coragem" para enfrentar a situação de um Brasil "ameaçado de um processo de desagregação. O governo Lula tem o desafio de conter essa desagregação" (Furtado, 2003, p. 7-8). Nos dois primeiros meses de governo, mesmo sob intensa popularidade, de um modo geral, a inversão de direção, salvo em alguns setores, ainda é tímida. $\mathrm{Na}$ área econômica, núcleo central e decisivo para qualquer mudança substantiva, os sinais, paradoxalmente, são de estranha continuidade. Por isso, Francisco de Oliveira, um dos intelectuais de esquerda fundadores do Partido dos Trabalhadores e renomado cientista social, cobra que o governo ouse "ultrapassar" a "era FHC". "O governo Lula ou ultrapassa a 'era FHC' ou estará definitivamente classificado dentro dela e, no futuro, historiadores e sociólogos reconhecerão um longo período de hegemonia neoliberal que engloba FHC e seus sucessores por um tempo que, hoje, não é previsível" (Oliveira, 2002, p. 6).

A inversão de direção e a ultrapassagem da era Cardoso pressupóem recuperar ou, quiçá, construir e dilatar a face pública do Estado brasileiro e torná-la efetivamente democrática para que se constitua em formulador e coordenador de políticas que garantam os múltiplos direitos sociais e subjetivos aos que, até o presente, foram excluídos. Para que isso seja possível, como lembra Celso Furtado, "o povo precisa perceber que a política não é jogo de elites, mas sim uma disputa pelo poder real" (Furtado, 2003, p. 7). Trata-se de transformar em poder de fato o 
acúmulo teórico e prático construído pelos movimentos sociais, sindicatos e partidos de esquerda na resistência mais longínqua dos 502 anos de colonização reiterada e, mais recentemente, das ditaduras e dos golpes contra a democracia efetiva. Em muitas oportunidades, vimos o Governo Cardoso não reconhecer os movimentos sociais organizados como interlocutores legítimos das negociações necessárias à superação de algumas fases da crise permanente em que vivemos. ${ }^{28}$

A síntese a que chegamos, nesta breve análise, é de que no campo educacional a "era Cardoso" foi de um retrocesso tanto organizativo como em termos pedagógicos. A atual LDB resultou do desprezo do Executivo ao longo processo de elaboração da Lei (de 1988 a 1996) pelo Fórum Nacional em Defesa da Escola Pública. O Conselho Nacional de Educação teve sua composição alterada para lhe retirar as prerrogativas de deliberação e submetê-lo às decisões do MEC. O Plano Nacional de Educação da sociedade brasileira, à semelhança da LDB, foi preterido pelo expediente questionável de o Executivo não respeitar sua precedência na entrada no Congresso. $\mathrm{O}$ ensino fundamental sofreu as imposições dos PCNs e da "promoção automática" que, aplicada a todas as séries, elevou as estatísticas oficiais, mas não os níveis de conhecimento dos alunos (o que veio a ser demonstrado pelas últimas avaliaçóes levadas adiante pelo $\mathrm{SAEB})$. A reforma do ensino médio e técnico foi imposta pelo Decreto $\mathrm{n}^{\mathrm{o}}$ 2.208/97 e pela Portaria no 646 de 1997 à revelia da resistência de muitas escolas ao conjunto de medidas que alteraram profundamente suas instituições. Os PCNs também foram construídos pelo alto, por uma comissão de especialistas que ignoraram décadas de debates dos pesquisadores e educadores da área. Sequer se levaram em conta as Diretrizes Curriculares elaboradas pelo Conselho Nacional de Educação.

A ultrapassagem que se impõe, no campo educacional, como tarefa para o novo governo, indica a necessidade de recuperar o imenso esforço de teorização e de propostas estruturadas pelas 34 instituições científicas, culturais, sindicais e políticas reunidas no Fórum Nacional em Defesa da Escola Pública. Mais que isso, cabe apreender os avanços significativos e ampliar as múltiplas experiências de governos populares municipais e estaduais, cujos protagonistas políticos pertencem à mesma base do atual governo e, muitos deles, compóem seus quadros dirigentes.

O foco organizativo e político-pedagógico deste resgate necessita alargar a compreensão do educativo para além dos muros da escola e impregnar-se da realidade dos múltiplos movimentos sociais e culturais da classe trabalhadora e de suas estratégias de produção da vida pelo trabalho. Este horizonte, sem dúvida, encontra uma síntese emblemática 
na pedagogia do Movimento dos Sem-Terra, para quem os processos educativos da classe trabalhadora não começam na escola nem acabam nela. Começam e acabam na sociedade, mas a escola pública, universal, laica, gratuita, democrática e, portanto, unitária (síntese do diverso) é um direito e uma mediação imprescindível nas suas lutas e na produção de sua humanização e emancipação.

\section{Recebido e aprovado em fevereiro de 2003.}

\section{Notas}

1. Ver a esse respeito Miriam Limoeiro Cardoso (1999).

2. As estratégias acordadas na Conferência previam: para necessidades diferentes, conteúdos, meios e modalidades de ensino e de aprendizagem diversas; prioridade a grupos em situação de privação: meninas, mulheres, portadores de necessidades especiais; sistemas de avaliação de resultados; condições materiais, físicas e emocionais para aprender, incluindo saúde, nutrição etc.; obrigação de o Estado fornecer educação básica com o concurso de organismos governamentais e não-governamentais, setor privado, comunidades locais, grupos religiosos, famílias; reconhecimento dos saberes tradicionais e do patrimônio cultural de cada grupo, por meio de modalidades educativas formais e não-formais (Shiroma et al., 2002, p. 58-59).

3. Estas considerações constam originalmente de Frigotto \& Ciavatta, 2002.

4. Parece-nos importante a análise de Luiz A. Cunha (2002) que sublinha a necessidade de percebermos que não se trata linearmente de uma subordinação das elites brasileiras aos organismos internacionais, gestores do grande capital. Inúmeros quadros de tecnocratas e intelectuais brasileiros fazem parte desses organismos. $\mathrm{O}$ autor analisa especificamente o caso da educaçáo e evidencia que os protagonistas das reformas no Governo de Fernando Henrique Cardoso, em grande parte, pertenciam a esses organismos. Maria Abadia da Silva (2002) sintetiza esta relação como sendo de "intervenção e consentimento".

5. Otavio Ianni (1978) oferece-nos também uma ampla análise sobre o movimento pendular das propostas de desenvolvimento no Brasil desde os anos de 1930, ora pendendo para uma associação subordinada com o grande capital internacional, ora buscando uma perspectiva de desenvolvimento com relações no plano internacional, mas de forma autônoma.

6. O ajuste é, na realidade, um reordenamento do capital, em nível global, na busca de recuperar taxas de lucro em queda. Vista de um ponto de vista histórico, a globalização, como analisa Paul Singer (1996), é a vingança do capital contra as conquistas e os direitos da classe trabalhadora.

7. Cabe ressaltar, como indica o Boletim Informação em Rede, da Ação Educativa, que "os serviços e produtos da Fundação Roberto Marinho e da Editora Globo são adquiridos em grandes quantidades, envolvendo valores elevados, sem concorrência ou licitação pública". Para se ter uma idéia da magnitude dos valores envolvidos, esse mesmo Boletim revela que o governo estadual do Maranhão assinou um convênio de R \$ 102 milhões com a Fundação Roberto Marinho para a instalação de 3.750 telessalas. (Boletim Informação em Rede, Ação Educativa, São Paulo, ago. 2001, 5, (38), p. 2).

8. Para uma ampla e profunda análise da perspectiva educacional centrada na "pedagogia das competências", ver Ramos (2001).

Educ. Soc., Campinas, vol. 24, n. 82, p. 93-130, abril 2003

Disponível em <http://www.cedes.unicamp.br> 
9. O SAEB "relaciona-se às demandas do Banco Mundial sobre a necessidade de avaliação do impacto do Projeto Nordeste, segmento Educação, no âmbito do IV Acordo MEC-BIRD (...), aliadas ao interesse do MEC de implementar um sistema mais amplo de avaliação da educação". O que redundou na criação do Sistema Nacional de Avaliação do Ensino Público de $1^{\circ}$ grau (SAEP) no final dos anos 80 . Sua implantação, por uma questão de recursos, veio a ocorrer em 1990 quando a Secretaria Nacional de Educação Básica viabilizou o primeiro ciclo do Sistema Nacional de Avaliação da Educação Básica (Bonamino \& Franco, 1999, apud Martins, 2001, p. 431-432).

10. Esta perspectiva pedagógica daquilo que "serve ao mercado" era a máxima adotada nas séries metódicas do SENAI desde sua origem e, agora, foi trazida para o sistema de educação básica. Ver a esse respeito Frigotto (1977).

11. Um único parlamentar do Partido da Frente Liberal ( $P F L$ ) da Bahia apresentou mais de mil destaques ao projeto de LDB que tramitou na Câmara e que em sua elaboração teve a participação massiva dos educadores.

12. Algumas das idéias desenvolvidas nesta seção constam de Ciavatta, 2002a.

13. Para citar os que conduziram à adoção do enfoque mão-de-obra para determinação de metas educacionais, isto é, à fixação de metas com base em projeçôes de necessidades futuras de mão-de-obra para o mercado de trabalho, a partir do Plano Nacional de Educação elaborado pelo Conselho Federal de Educação em 1962: Programa de Ação Econômica do Governo (1964-1966); Plano Decenal de Desenvolvimento Econômico e Social (19671976); Programa Estratégico de Desenvolvimento (1968-1970); V Plano Nacional de Desenvolvimento da Nova República - 1986-1989, aprovado pelo presidente José Sarney na forma da Lei no 7.486 de 6/6/1986 (Horta, 1982, p. 127 ess. E 1997, p. 169 e ss.).

14. A elaboração do PNE da sociedade brasileira tem se realizado, a partir da aprovação da atual LDB em 1996, por meio dos Congressos Nacionais de Educação (CONEDs). Buscando garantir o espaço público de debate historicamente preenchido pelas Conferências Brasileiras de Educação (CEBs, 1980 a 1991), o I CONED (1996) e os subseqüentes, II CONED (Belo Horizonte, 1997), III CONED (Brasília, 2000), IV CONEd (São Paulo, 2002), mantêm o mesmo tema central, "Educação, Democracia e Qualidade Social", como um esforço coletivo de consolidar um Plano Nacional de Educação que "garanta direitos, verbas públicas e vida digna".

15. "Apesar da propaganda oficial em seu favor, o FUNDEF pode enfraquecer outros níveis e modalidades de ensino (educação infantil, ensino médio e supletivo), cujas matrículas de trabalhadores não são levadas em conta na distribuição do FUNDEF. Além disso, o discurso federal de valorização do ensino fundamental e do magistério não encontra a contrapartida dos recursos federais que são ínfimos e bem menores do que os devidos legalmente" (Davies, 1999, p. 1).

16. O fenômeno não é novo; ver Franco, 1984.

17. No balanço sobre o FUNDEF, divulgado pelo MEC em outubro de 2000 (www.mec.gov.br), as matrículas estaduais e municipais no Ensino Fundamental Regular (EFR) "teriam crescido 2,3 milhões nas redes públicas de 1997 a 1999, graças ao FUNDEF. Entretanto, a propaganda oficial não revela que este aumento se deve em grande parte à inclusão, no EFR, de 785 mil matrículas de classes de alfabetização (CA), de 100 mil de educação de jovens e adultos (EJA), e cerca de 400 mil perdidas pelo setor privado e provavelmente incorporadas às redes municipais, sem falar na falsificação de matrículas, problema reconhecido pelo próprio Ministério da Educação, e que gerou portaria cancelando matrículas de redes de alguns governos ansiosos por aumentar a sua fatia do FUNDEF" (Davies, 2003, p. 1).

18. No momento em que estávamos produzindo este texto, o jornal $O$ Globo apresentou uma matéria sobre uma auditoria que estava sendo feita no Ministério da Educação, a qual nos dá conta de que somente em dezembro de 2002, último mês do Governo Cardoso, foram 
autorizados 434 novos cursos superiores e que "entre as irregularidades encontradas está a autorização de cursos em instituiçôes universitárias que sequer estavam credenciadas para funcionar" ( $O$ Globo, 26/2/2003, p. 10).

19. De acordo com o relatório do Banco Mundial de 2002, de 89\% em 1996 para 96\% em 2001. Ver Relatório do Banco Mundial no 24413-BR - Educação Municipal no Brasil. Recursos, Incentivos e Resultados. Vol. 1, dezembro de 2002.

20. Para uma compreensão mais ampla da descentralização da educação fundamental no contexto das políticas federativas do Governo Cardoso, ver Arretche (2002).

21. Se tomarmos os dados do relatório "Futuro em Risco", patrocinado pela Inter-American Dialogue e pelo Banco Interamericano de Desenvolvimento, que trata da crise da educaçáo na América Latina e das consequiências na estagnação econômica, veremos o quanto falaciosa e enganosa é a propaganda de que as reformas educacionais, mormente do ensino fundamental, coadunam-se com os desafios da competitividade internacional no contexto de sociedades "globalizadas". Ao passo que o custo aluno/ano, base do FUNDEF, é de aproximadamente 400 reais, aquele relatório nos mostra que o grau médio de gasto aluno/ano para o ensino fundamental e médio, nos países desenvolvidos, é de 4.170 dólares (ver Frigotto, 2000).

22. O ENEM e o Provão, respectivamente no ensino médio e superior, reproduzem a mesma lógica.

23. Ver a esse respeito Confederação Nacional dos Trabalhadores em Educação (1999 e 2001) e Carlos Abicalil (2002).

24. Agradecemos à professora Maria Célia Freire de Carvalho as indicaçôes legais e os comentários críticos sobre o tema.

25. Posteriormente, no Governo Itamar Franco (1992-1993), por intermédio da Lei no 8.948 de 8/12/1994, fica instituído o Sistema Nacional de Educação Tecnológica (art. 1º), que vai transformar todas as Escolas Técnicas Federais em Centros Federais de Educação Tecnológica (CEFETs), obedecidos os critérios nos termos da Lei (art. $3^{\circ}$ ). Depois da promulgação da LDB, Lei no 9.394 de 20/12/96, e do Decreto no 2.208 de 17/4/1997, o Decreto no 2.406 de $27 / 11 / 1997$ virá regulamentar o art. 40 da LDB e o art. $2^{\circ}$ do Decreto $n^{\circ} 2.208$ que distingue três níveis da educação profissional, o básico, o técnico e o tecnológico, este último "correspondente a cursos de nível superior na área tecnológica, destinado a egressos do ensino médio e técnico" (inciso III).

26. Parte destas reflexōes constam de Frigotto \& Ciavatta, 2002.

27. O documento não se estende sobre o significado específico do modelo. Para uma revisão da polêmica que envolve o conceito de competências, ver, entre outros, Deluiz, 1995; Ramos, 2001; Tanguy, 2002.

28. A primeira delas foi a resposta policial à greve dos petroleiros em 1996. No movimento docente, greves prolongadas e desgastantes foram resultado da política do MEC de não receber os representantes dos servidores públicos para negociar as reivindicações da categoria.

\section{Referências bibliográficas}

ABICALIL, C.A. Sistema Nacional de Educação Básica: nó da avaliação? Educação \& Sociedade., Campinas, vol. 23, n. 80, p. 255-276, set. 2002. Número especial.
ANDERSON, P. Entrevista. Folha de S. Paulo, São Paulo, 10 nov. 2002, Caderno especial, p. 9-10.

Educ. Soc., Campinas, vol. 24, n. 82, p. 93-130, abril 2003

Disponível em <http://www.cedes.unicamp.br> 
ARRETCHE, M. Relações federativas nas políticas sociais. Educação \& Sociedade, Campinas, v. 23, n. 80, p. 25-48, set. 2002. Número especial.

ARRIGHI, G. A ilusão do desenvolvimento. Petrópolis: Vozes, 1998.

BOURDIEU, P.; WACQUANT, L. A nova bíblia do tio Sam. Le monde diplomatique, edição brasileira, v. 1, n. 4, ago. 2000.

CARDOSO, M.L. A ideologia da globalização e descaminhos das ciências sociais. In: GentiLI, P. (Org.). Globalização excludente: desigualdade, exclusão e democracia na nova ordem mundial. Petrópolis: Vozes, 1999.

CASTRO, M.H. Trabalho \& educação (entrevista). Jornal do Brasil, Rio de Janeiro, 06 ago. 2000, Caderno especial.

CHESNAIS, F. A mundialização do capital. São Paulo: Scrita, 1996.

CIAVATTA, M. A construção da democracia pós-ditadura militar: políticas e planos educacionais no Brasil. In: Fávero, O.; Semeraro, G. (Org.). Democracia e construção do público no pensamento educacional brasileiro. Petrópolis: Vozes, 2002.

CIAVATTA, M. Trabalho e educação em uma perspectiva transformadora. In: CONFERENCIA Regional de Educação, 2002, Rio de Janeiro. Rio de Janeiro: SEE, 2002a (mimeo).

CONFEDERAÇÃO NACIONAL DOS TRABALHADORES EM EDUCAÇÃO. Retrato da Escola. Brasília, DF: CNTE, 1999 (CD-ROM).

CONFEDERAÇÃO NACIONAL DOS TRABALHADORES EM EDUCAÇÃO. Retrato da Escola II. Brasília, DF: CNTE, 2001 (CD-ROM).

CONSELHO DE DIRETORES DOS CENTROS FEDERAIS DE EDUCAÇÃO TECNOLÓGICA. A reforma da educação brasileira nas Instituiçôes Federais de Educação Tecnológica. Brasília, DF, nov. 2002 (mimeo).

CUNHA, L.A. Educação, Estado e democracia no Brasil. São Paulo: Cortez; EDUF; FLACSO, 1991.

CUNHA, L.A. Educação brasileira: projetos em disputa. São Paulo: Cortez, 1995.

CUNHA, L.A. As agências internacionais e a reforma brasileira do ensino técnico: a crítica da crítica. In: REUNIÃO de Intercâmbio do GT "Estado e Política Educacional”, 2002, São Paulo. São Paulo: AnPed, 2002. 
DAVIES, N. O FUNDEF e o orçamento da educação: desvendando a caixa preta. Campinas: Autores Associados, 1999.

DAVIES, N. Governo FHC: toda criança na escola? quando $1+1$ é mais do que 2... nas estatísticas oficiais! Niterói: UFF, 2003. p. 1-12 (mimeo).

DÉBORD, G. A sociedade do espetáculo: comentários sobre a sociedade do espetáculo. Rio de Janeiro: Contraponto, 1997.

DELUIZ, N. Formação do trabalhador: produtividade e cidadania. Rio de Janeiro: Shape, 1995.

FERNANDES, F. Diretrizes e bases: conciliação aberta. Revista Sociedade e Universidade, São Paulo, 1991.

FIORI, J.L. O nome aos bois: instituto da cidadania. São Paulo: Fundação Perseu Abramo, 2002.

FRANCO, M.C. Lidando pobremente com a pobreza. Cadernos de Pesquisa, São Paulo, n. 51, p. 13-32, nov. 1984.

FRIGOTTO, G. Efeitos cognitivos da escolaridade do SENAI e da escola acadêmica convencional: existe uma escola para cada classe social? 1977. Dissertação (Mestrado) - Fundação Getulio Vargas, Rio de Janeiro.

FRIGOTTO, G. Educação e crise do capitalismo real. São Paulo: Cortez, 1995.

FRIGOTTO, E. Construção curricular e demarcação discursiva: gênese e afirmação da proposta Escola Cidadã de Porto Alegre. 1999. Tese (Doutorado) - Pontifícia Universidade Católica, Rio de Janeiro.

FRIGOTTO, G. Educação, trabalho e desenvolvimento: contradições da atual política educacional. Revista da DIRENG - Diretoria de Engenharia da Aeronáutica, v. 10, n. 18, nov. 2000.

FRIGOTTO, G.; CIAVATTA, M. (Org.). Teoria e educação no labirinto do capital. 2. ed. Petrópolis: Vozes, 2001.

FRIGOTTO, G.; CIAVATTA, M. (Coord.). Caminhos para a redefinição da política pública para a educação tecnológica e o sistema de formação profissional continuada: proposições, Niterói, 2002 (mimeo).

FRIGOTTO, G.; CIAVATTA, M. Educar o trabalhador cidadão produtivo ou o ser humano emancipado. Trabalho, Educação e Saúde, Rio de Janeiro, v. 1, n. 1, p. 45-60, 2003. 
FURTADO, C. A alca e o fim da soberania. Brasil de Fato, São Paulo, n. 0, 25 jan. 2002 .

GITAHI, L.; RABELO, F. Os efeitos sociais da microeletrônica na indústria metal-mecânica brasileira: o caso da indústria de informática. In: SEMINÁRIO Padrões Tecnológicos e Políticas de Gestão: processos de trabalho na indústria brasileira, maio 1997, Campinas. (mimeo).

HOBSBAWM, E. A era dos extremos. São Paulo: Cia das Letras, 1995.

HORTA, J.S. Liberalismo, tecnocracia e planejamento educacional no Brasil. São Paulo: Autores Associados; Cortez, 1982. p. 2-55.

HORTA, J.S. Plano Nacional de Educação: da tecnocracia à participação democrática. In: CuRY, C.R.J. et al. (Org.). Medo à liberdade e compromisso democrático: LDB e Plano Nacional de Educação. São Paulo: Ed. do Brasil, 1997.

IANNI, O. Estado e planejamento econômico no Brasil (1934-1970). 2. ed. São Paulo: Civilização Brasileira, 1978.

MARTIN, P.H.; SCHUMANN, H. A armadilha da globalização. 5. ed. São Paulo: Globo, 1999.

MARTINS, A.M. A autonomia outorgada: uma avaliação da política educacional no Estado de São Paulo (1995-1999). Ensaio, Rio de Janeiro, v. 9, n. 33, out./dez. 2001, p. 415-442.

MÉSZÁROS, I. Para além do capital. Campinas: UNICAMP; Boitempo, 2002.

NEVES, L.M.V. Educação e política no Brasil de hoje. São Paulo: Cortez, 1994.

NEVES, L.M.V. (Org.). Politica educacional nos anos 90: determinantes e propostas. Recife: Ed. Universitária, 1995.

NEVES, L.M.V. Um caminhar para o mesmo lugar. In: LESBAUPIN, I. (Org.). O desmonte da naca: balanço do governo FHC. Petrópolis: Vozes, 1999.

NEVES, L.M.V. Brasil 2000: nova divisão de trabalho na educação. São Paulo: Cortez, 2000a.

NEVES, L.M.V. (Org.). Educação e política no limiar do século XXI. Campinas: Autores Associados, $2000 \mathrm{~b}$. 
NEVES, L.M.V. Brasil século XXI. Rio de Janeiro: UfF, 2002 (mimeo).

OLIVEIRA, F. O reinado de 20 anos. Folha de S. Paulo, São Paulo, 13 out. 1996.

OLIVEIRA, F. A nova hegemonia burguesa no Brasil dos anos 90 e os desafios de uma alternativa democrática. In: FrigotTo, G.; CiavatTA, M. Teoria e educação no labirinto do capital. 2. ed. Petrópolis: Vozes, 2001.

OLIVEIRA, F. Entre São Bernardo e a Avenida Paulista. Folha de S. Paulo, São Paulo, 29 dez. 2002.

PETRAS, J.; Veltmeyer, H. Brasil de Cardoso: a desapropriação do país. Petrópolis: Vozes, 2001.

PINTO, J. M. R. Financiamento da educação no Brasil: um balanço do governo FHC (1995-2002). Educação \& Sociedade, Campinas, v. 23, n. 80, set. 2002. Número especial.

PLASTINO, A. El rol del Estado en la educación superior. In: SEMINÁRIO de Integração de Universidades Brasil-Argentina, 1991, Recife. Recife: UCPe, 1991. (mimeo).

RAMOS, M. A pedagogia das competências: autonomia ou adaptação? 2. ed. São Paulo: Cortez, 2001.

RIBEIRO, R. J. A sociedade contra o social. São Paulo: Cia das Letras, 2000 .

RODRIGUES, J. O moderno principe. Campinas: Autores Associados, 1998.

SADER, E. Lula, o pós-neoliberalismo chegou ao Brasil? Revista Sem Terra, São Paulo, v. 5, n. 17, out./dez. 2002.

SANTOS, W.G. Ordem burguesa e liberalismo politico. São Paulo: Duas Cidades, 1978.

SAVIANI, D. A nova lei da educação. Campinas: Autores Associados, 1997.

SCHAFF, A. A sociedade informática. São Paulo: UNESP; Brasiliense, 1990.

SILVA, M.A. Intervenção e consentimento: a política educacional do Banco Mundial. Campinas: Autores Associados, 2002. 
TANGUY, L. De la évaluation de los puestos de trabajo a la de las cualidades de los trabajadores: definiciones y uso de la noción de competencias. In: Dossi, E.; TANGuY, L.. São Paulo: IIEP, 2002 (mimeo).

WCEA. Satisfacción de las necesidades básicas de aprendizaje: una visión para el decenio de 1990. In: CONFERENCIA Mundial sobre la Educación para Todos, 1990, Jomtien, Tailândia. 